\title{
LINGUODIDACTIC CORRECTNESS AS A PRINCIPLE OF FOREIGN LANGUAGE TEACHING
}

Necessity to proceed to teaching foreign languages on a scientific basis and not to separate the linguistic aspect from the pedagogical and psychological was emphasized by the linguists in the last century. H. E. Palmer theoretically developed this requirement by introducing the term "principles of linguistic pedagogy" into scientific usage.

The article analyses a problem that has become especially actual in modern linguodidactics, namely: the need to justify and adhere to the position that the language is described not "in itself and for itself", but taking into consideration the fact that its description should meet the obligatory needs of teaching language as means of transmitting information.

The pedagogical approach to language makes the linguists admit that the structure of the language differs from other structures. First, it is an active dynamic model ("meaning - text"); secondly, it has several levels, and the most profound is fundamental. The following is the level of intentions, which is indirectly correlated with the level of meanings of words. Third, the action of the model is related to the direction of speech communication and the correctness of what is expressed in the speech utterance.

An essential feature of modern pedagogical linguistics is to take into account the peculiarities of linguistic communication, which are manifested, in particular, in the correct usage of expressing means of the foreign language tools necessary for adequate exchange of ideas in the communication process.

The article has clarified the following types of correctness: correctness usage of language behaviour, correct use of lexical units, correctness of syntactic forms, communicative correctness, semantic correctness, pragmatic correctness, and also defines the relationship between the concepts of correctness and speech etiquette.

In general, the description of correctness in speech behaviour was performed within the framework of pedagogical tasks. For the first time, correctness has been studied as a deep principle of interaction of didactic laws with structural elements of language, which may have practical value for the development of innovative methods of teaching a foreign language.

Key words: linguodidactic correctness, etiquette, formal and informal vocabulary, standard, lexical correctness and correctness of structural models, communicative correctness.

The statement of the issue. In the last twenty-five years within pedagogics there has been a great deal of interest in "correctness" to such an extent that politeness theory could almost be seen at a sub-discipline of pedagogics. Much has been written (comparatively little based on empirical research) and different theories and paradigms have emerged. Nowadays the methods of linguistic analysis based on pedagogical linguistics, attracted the attention of the scientists and directed it towards the construction of theories which could provide interpretations for various linguistic phenomena: the language is being learned, has been changing and the linguistic phenomena can be explained and serve as a means of cognition humanity.

Correspondingly from the development of linguistic description to theory, the notion of linguistic correctness has played a definite role in all types of correctness assessment elicited

\footnotetext{
*C) Lebedeva N.M.
} 
by linguists from native speakers. Besides the theoretical investigation, there are the standpoints of language teaching which do not allow only taking one of theoretically oriented linguists as for the basis of teaching languages. It is broadly acknowledged that language teaching needs its own theory, based on pedagogical principles, depending on the special goals of teaching language and conditions under which it has to take place.

The analysis of relevant research. In recent years linguists and teachers have paid much attention to the fact that languages are made by people along with the cultural, political and historical development of a society. The problem of linguistic analysis based on pedagogical principles drew attention of Ukrainian and foreign linguists such as L. Verba [1], G. Leech [3], H. Palmer [7] and others.

On the other hand, linguists and teachers are aware of the fact that much of the structural properties of languages is due to processes of systematization and are restrained by universal properties of human cognition. In conformity with this fact the concept of linguodidactic correctness plays an undoubted role in all types of correctness assessment elicited by linguists and teachers from learners and users.

The purpose of the article is to provide how the social reality of the rules of speech etiquette and behaviour in the society, and with that, the objectivity of correctness concepts (and common concepts) generally are constituted and achieved in the society; to analyse how the individuals exhibit strong normative attitudes and behaviour with respect to linguistic and pedagogical correctness.

The body of the research. The notion of linguistic correction has always been a principal notion in theoretical studies which has been interested in analysing the problem - "what correct utterances are in a language" and "what is the correct use of them in the process of communication" [7, p. 13]. For instance, correctness as a subject of our article presents a problem in definition. There exist many definitions of the term correctness in different dictionaries of the English language. Logically these definitions do not account for all the known facts and have, in some cases, no theoretical foundation, they are worthy of attention and they favour the definitions that correctness core to behave or speak in a way that is generally accepted and approved of; conformity to accept social standards [2; 4-8]. Dictionaries and thesauruses have proved lists of correct basic expressions, standard speech patterns and literary examples of correct standard speech patterns plus examples of their use. These two aspects are fundamental and classically called by the linguists "forms and functioning of the language" [1, p. 54-57].

Though all scholars and teachers of language start from the basic assumption that a linguistic theory should take into account standard expressions and their normative use and their correct use in a comprehensive manner. The ways and kinds of descriptions differ considerably, depending on different basic assumptions and goals, as does the degree o correctness.

Formulating the idea that correctness of speech is based on pedagogical principles we should conclude that it is in itself represents ethical correctness: of all speakers of the language use the same vocabulary. There is a common stock of every day words (neutral words) and people in specialized fields of knowledge use the words which most people outside of that field may not know (formal words). The whole vocabulary of a language is organized in subgroups of items for which certain subgroups of people know and handle the correctness notions with respect to the form of a word and with respect to its use. The Simple Correctness Standard of being on the list or not cannot be applied to the new words or to foreign words newly introduced into the language. For instance: in community $X$ the correctness $A$ hold; and in the community $Y$ - the rules of correctness $B$. Thus we take into account that pedagogical linguistics includes an empirical fact, which is a social one. It investigates rules of speech etiquette [3] correctness in behaviour, their functions, and arguments with respect of assumed values and paradigms. Correctness Standard may be represented in the following scheme 1. 
Correctness Standard

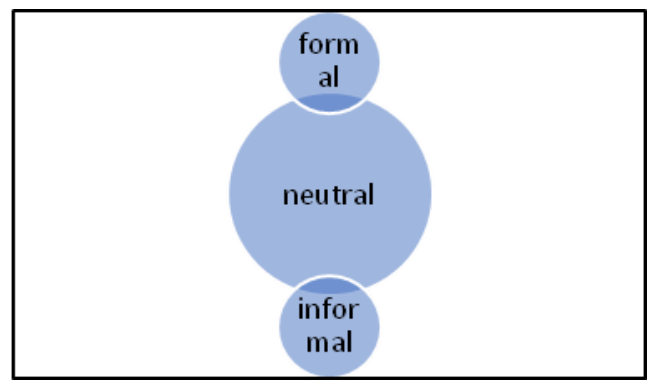

Scheme 1. Correctness Standard

On recognition of the nature of the given problem we can suggest that rules of correctness are represented by extralinguistic factors. The correctness notions exist in a community by being the contents of standard language. In this way, correctness concepts, which as concepts in a certain sense are physic entities, have a social reality and objectively above or outside the individuals who comprehend them by constructing a physic representation of them. Their correctness is socially established in various degrees of formality from providing models of correctness to providing codifications of the rules of etiquette.

The actual words conventionally present an open list, i.e. the list to which new words can be added under certain circumstances. The set of frequently used words consists of a subject of the morphologically possible words plus a subject of loans that are not yet adapted to native morphological restrictions (barbarisms). After their adaptation the latter are counted as members of the first subject. Since words are coded separately, the correctness notion is very simple: what is in the list, i.e. the lexicon, is correct. The lexicon is stored in the "collective memory" of the speech community. Often it is codified lexica in the form of books or computer discs. For the individual speaker, on the other hand, basically what is familiar to him, as a word of his language, is correct. He will base his correctness judgements on his own memory in the first place, but accept additionally what is stored in public lexica.

In everyday speech correction activity, oriented to words the written of formal standard, depends on how much an individual is conscious of speaking a language different from written speech. Written language has no influence of everyday speech, though it has some nominative force with respect to formal oral language use.

If a new lexical unit is acceptable to a significant group, then it will be adopted first by that group and later in the speech of community as a whole - that it is useful there.

The moment a word is adopted by a group, i.e. has been put into use, it acquires correctness standards: there are now criteria for its further use and recognition of its proper form and appearance.

General notions of correctness are not developed for their own sake but are developed and employed when they are really necessary. This is also the reason that spoken language is much free in syntax, even ignoring syntactic form altogether in utterances for which the interpretation is largely supplied. There are many situations where people do not speak in sentences, but pronounce only one or several words, in order that is certainly not syntactic, and where contextual, gestural, and intonational clues suffice for interpretation. These situations hold especially when emotions are being expressed: the content is known to the hearer already and the speaker knows it. If interpretation of speech is secured anyhow, syntax does not matter.

Spoken language is syntactically less restricted in general, besides having certain standard patterns that are not used in written language. In speech people normally accept this freedom from a strict notion of syntactic correctness, except in situations where it would interfere with understanding and in teaching situations. In the latter, even when communication works well with unregulated constructions, parents and teachers usually 
correct students and language learners so that they can learn the syntax needed in situations lacking sufficient clues for interpretation, as in communication about unknown events, objects, relationships and for written language generally. Motivation for learning syntax depends on several factors: the prestige of the people providing models of correct speech, the wish to please them and to avoid neglect and other penalties and the drive to get something unknown and interesting. Situations of learning syntax do not provide motivation for learning syntax because in them, syntax is not really needed.

The syntax of a language supplies a socially controllable immediate structure between basic cognitive operations, or at least possibilities to specifying such operations, and publicly accessible and controllable states of affairs. Thus syntax which is learned vis-à-vis the facts, provides a socially induced structuring - which the facts and basic cognitive types of operation permit. We can suggest that syntax, with respect to situations and events and their interrelation, selects structures in a socially coordinated way. Situations and their relationships represented under this selective view are what we call facts. So facts are language-dependent selections arranging and systematizations which the world permits, by being as it is. Facts are arranged within the possibilities left open by the basic cognitive restrictions on handling data provided by perception and lexical information.

Written language per se is largely independent of the situations of writing and reading. It has to make explicit, by description, information which in daily speech can be available in the situations. Besides the use of more lexical items, this requires a large amount of socially controllable syntactic constructions. There are also situations in which spoken English requires strong syntactic restrictions. Formal speech is an example. Strict syntactic form is also necessary in stories and songs that report history for keeping the facts straight about the events that happened long ago and are not recoverable independently. The exactness required in these matters is not possible without proper syntactic form. Syntactic form is stabilized in "frozen" texts generally, whether oral or written ones; that these frozen texts are reference points or models for the notions of syntactic correctness has led, in the history of languages, to different degrees of standardization and also to tensions between conservative models and new models that are a compromise between the old models and new developments due to change in spoken language, change of condition of life, and modernization of technologies.

Thus we have a hierarchy of notions that pertain to acceptability and correctness of syntactic form: 1) syntactically correct according to the standard of written language; 2) syntactically incorrect according to the written standard but acceptable in everyday spoken language; 3) syntactically incorrect and not acceptable in everyday spoken language of native speakers; 4) otherwise incorrect and unacceptable but can, if at least understandable and interpretable, be acceptable when used by people of whom one does not expect correct speech.

What is not understandable and not interpretable is absolutely unacceptable. If one has higher expectations with regard to the ability to a person to handle the correctness notions a language, one will find that person's production of incorrect speech were unacceptable; with higher expectations, that is acceptability of incorrect speech is lower.

Thus we have analyzed notions of correctness that pertain to linguistic form of communicational means.

Formulating correctness conditions for texts is not a matter of finding correctness conditions for linguistic forms. Correctness of texts, in some of its aspects belongs under the heading of correctness of use of linguistic forms, together with semantic and pragmatic correctness of actions and series of actions. Two different kinds of correctness are involved in both, pragmatic correctness, including aspects of stylistics and correctness of texts:

1) correctness of the use of linguistic forms.

2) correctness of communication as a part of rational interaction.

Concepts are criteria or patterns in the minds of language users guiding the use of the expressions. They have an intersubjective and objective character because they are formed

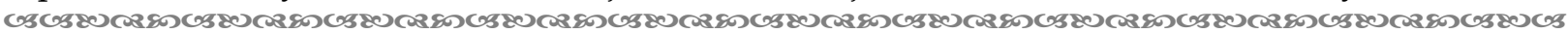


under social control and remain socially controlled by a public nominative force enacted in the special community on its members by approval or disapproval in situations of use of the words that express these concepts. This intersubjective and objective aspect of a concept is thought of as somehow a projection that is outside the individuals, a public concept, which regulates all the individual subjective concepts in the heads of the speakers in such a way that these fit within the projection. The public concept has its reality in the trait of regularity that corresponds with the occurrences of its expression in satisfaction situations. The judgement about whether the expression has been applied correctly or not is guided by aspects of relevance under which certain regularities are matter of attention.

As to notions of semantic correctness we should examine them with respect to situations and then with respect to constellations. On the basis of this, a notion of structural semantic correctness is defined as independent of situations use. The definitions are formulated for indicative sentences, i.e. for assertions. This makes the interdependence between rules of etiquette and the notion of truth especially evident. For other types of sentences the definitions have to be formulated accordingly in terms of their satisfaction conditions:

- Correctness with respect to situations uses a predicative expression a correctively in s or with respect to $s$ if and only if the sentence in which it occurs is true in $s$, or satisfied in $s$. The predicator $A$ is used positively correctly in $s$ if and only if This/here is $A$ is true in $S$, and negatively correctly if and only if This/Here is not $A$ is true in $s$.

- Correctness with respect to constellations: a speaker/hearer uses expression $A$ correctly with respect to a constellation if this constellation makes the sentence containing $A$ true, or satisfies it.

- Weak correctness: $A$ is used weakly semantically correctly in utterance if the speaker/hearer who uses $A$ accepts the distribution of satisfaction constellations with respect to this utterance. That means when confronted with a constellation, he will identify the constellation correctly as a satisfaction or dissatisfaction constellation, i. e. when confronted with a constellation he will use the expression correctly. The notion of weak semantic correctness is thus a dispositional notion which can only be partly reduced to non-dispositional terms by following formulation: a speaker $S$ uses an expression $A$ weakly semantically correctly in a speech situation: if $S$ uses $A$ in a satisfaction or dissatisfaction constellation or situation then it holds that $S$ uses $A$ weakly correctly if and only if $S$ uses $A$ correctly.

- Structural semantic correction: an expression is structurally semantically correct if there is a possible constellation or situation in which it is used semantically correctly. It is structurally semantically incorrect if no such constellation is possible. A great number of the semantic correctness notions of the second level seem not to be part of the linguistic competence of the average speaker/hearer. Nevertheless speech community as a whole can employ by the way of a division of linguistic labour which to a large extent is identical with the division of scientific and technical labour in a community.

Conclusions. Thus the purpose of teaching correctness in a foreign language lesson is to develop speech skills that would allow the students to use them in speech practice at the level of everyday communication. It helps to develop students common language, intellectual, cognitive abilities, mental processes, their wish to communicate showing their emotional feeling in different types of collective intercourse. The notion of correctness that regulates unrestricted communication among members of a speech community is based on rationality and cooperation as universal principles of human interaction, and on particular conventions of speech community.

Perspectives of our following research lie in applying and developing linguodidactic methods of foreign language teaching.

\section{Bibliography:}

1. Верба А. Т. Порівняльна лексикологія англійської та української мов. Вінниця : Нова Книга, 2003. 160 c. 
2. Current Literary Terms. A Concise Dictionary of their Origin and Use / A. F. Scott. Macmillan, 1980. $324 \mathrm{p}$.

3. Leech Geffrey. Principles of Pragmatics. London. New York : Longman, 1983. 257 p.

4. Longman Dictionary of Contemporary English. New Edition. For advanced learners. 2010. 2082 p.

5. Longman Exams Dictionary. Edinburg Gate, England : Pearson Education Limited, 2009. 1883 p.

6. Oxford Advanced Learner's Dictionary. Oxford University Press. Oxford, 2005. 1800 p.

7. Palmer H. E. Teaching English as a Foreign Language. Logos studies in language \& linguistics. Pioneers of ELT (Volume 2) / ed. by Richard C. Smith. Routledge, 2003. 465 p.

8. UseEnglishWords.com. 2020. URL : https://useenglishwords.com/correctiveness

\section{References:}

1. Verba, L. T. (2003). Porivnialna leksykolohiia anhliiskoi ta ukrainskoi mov [Comparative lexicology of English and Ukrainian languages]. Vinnytsia: Nova Knyha [in Ukrainian].

2. Scott, A. F. (Ed.) (1980). Current literary terms: a concise dictionary of their origin and use. Macmillan [in English].

3. Leech, G. (1983). Principles of Pragmatics. London. New York: Longman [in English].

4. Longman Dictionary of Contemporary English. (2010). New Edition. For advanced learners [in English].

5. Longman Exams Dictionary. (2009). Edinburg Gate, England: Pearson Education Limited [in English].

6. Oxford Advanced Learner's Dictionary. (2005). Oxford University Press. Oxford [in English]

7. Palmer, H. E. (2003). Teaching English as a Foreign Language. In Logos studies in language $\mathcal{E}$ linguistics. Pioneers of ELT. (Vol. 2). Routledge [in English].

8. UseEnglishWords.com. (2020). Retrieved from https://useenglishwords.com/correctiveness [in English].

Аебедєва Н. М., orcid.org/0000-0002-6297-106X

Франичзова К. С., orcid.org/0000-0002-0959-2669

\section{ЛІНГВОДИДАКТИЧНА КОРЕКТНІСТЬ ЯК ПРИНЦИП НАВЧАННЯ ІНОЗЕМНОЇ МОВИ}

Ще на початку минулого століття вчені-лінгвісти наголошували на тому, що у процесі навчання іноземної мови на науковій основі не можна відривати хінгвістичний аспект від педагогічного і психологічного. Г. Пальмер теоретично розробив ияю вимогу, ввівщи у науковий обіг термін «принциип хінгвістичної педагогіки».

У статті розглянуто проблему, яка набула особливої актуальності в сучасній лінгводидактиці, а саме: необхіність облрунтування $i$ дотримання положення, щз мова описується не «у собі і для себе», а з урахуванням того, ще ї описання повинно максимально відповідати потребам навчання цієё мови як засобу передачі інформації.

Педагогічний підхід до мови передбачае формування уявлення про ї структурну відмінність від інших мов. По-перше, изе діюча динамічна модель («смисл-текст»); по-друге, вона має кілька рівнів, причому основоположним є найбільи глибинний. Наступним вважаеться рівень намірів, який непрямим способом співвідноситься з рівнем значень слів. По-трете, дія моделі пов'язана зі спрямуванням мовленневого спілкування $і$ коректністю того, що виражено у висловлюванні.

Суттевою особливістю сучасної педагогічної лінгвістики є врахування особливостей мовної комунікацї, що виявляються, зокрема, у коректності використання засобів іноземної мови, необхідних для адекватного обміну думками у процесі спілкування.

у статті проаналізовано такі види коректності: коректність мовної поведінки, коректність уживання лексичних одиниць, коректність синтаксичних форм, комунікативна коректність, семантична коректність, прагматична коректність, а також визначено співвідношення між поняттяли коректності і мовного етикету. 
В иілому опис коректності у мовленневій поведінці виконувався у рамках педагогічних задач. При цุвому вперше коректність досліджено як глибинний принции взаємодї дидактичних законів зі структурними елементами мови, що може мати практичну иінність для розробки інноваційних методів навчання іноземної мови.

Ключові слова: лінгводиактична коректність, етикет, формальна $і$ неформальна лексика, стандарт, лексична коректність $і$ коректність структурних моделей, комунікативна коректність.

Дата надходження статті: 27.10.2020 p.

Рецензент: доктор педагогічних наук Чумак А.В.

\section{ФОРМУВАЯЬНЕ ОЦІНЮВАННЯ ЯК ЗАСІБ ПІДТРИМКИ І РОЗВИТКУ ЗДОБУВАЧІВ ОСВІТИ ПОЧАТКОВОЇ ШКОЯИ}

У статті розглянуто проблему, яка останнім часом набувае все більшої актуальності в національній педагогічній науц̧і й освітянській практиці, а саме: введення різних видів оцінювання в систему діяльності школи XXI століття. Серед изих видів украйнські й зарубіжні науковці виокремлюють формувальне, підсумкове й рівневі оцінювання навчальної діяльності здобувачів освіти початкової школи.

Відзначається, що особливого значення провідні вчені-методисти надають формувальному оцінюванню навчальних можливостей та інтелектуального поступу учнів молодших класів. Підкреслюеться, що аспекти формувального оцінювання розроблювалися й нині продовжують досліджуватися багатьма широко відомими та знаковими вченими-теоретиками інауковияли-аналітиками освітнього процесу, серед яких Ш. Амонашвілі, Б. Ананьєв, М. Вашуленко, Д. Колесов, А. Маркова, Т. Матіс, О. Орлов, О. Савченко, Г. Цукерман та ін. Докладно аналізуеться механізм дї формувального оцінювання в якості засобу підтримки та розвитку особистості учнів сучасної школи, передусім початкової. Акцентуеться на трьох базових конструентах цุвого механізму: а) функцї̈ збирання різноманітної психологічної тадитиноцентричної інформації, б) процесі багатовимірного спостереження за навчальною поведінкою ци інтелектуальним прогресом учнів початкової школи, в) забезпеченні результативного зворотного зв'язку з молодиими школярами. Розглядаютовся конкретні техніки формувального оцінювання, якими вчителі початкової школи ефективно послуговуються на практиці. Обсервуються педагогічні переваги формувального оциінювання, виявлені діяльністю провідних учителів сучасної школи. 3-поміж изих переваг виділяються такі: націленість на визначення індивідуальних досягнень кожного учня, уникнення прийому порівнювання навчальних досягнень різних дітей; застосування зрозумілих изілей та критеріїв, за якими оцінюють діяльність школярів; визначення вектора навчання й перспектив розвитку кожної дитячої особистості. Узагальнюється, що формувальне оцінювання дієво допомагає дітям поліпшити свої результати в навчанні, дае змогу визначати подальші завдання власного розвитку та способи їх здійснення. Послідовно обьрунтовуеться, щьо формувальне оцінювання єефективним інструментом педагогічної дї $і$ сприяе стратегї успішної самореалізації сучасних учнів.

Ключові слова: формувальне оцьнювання, учні початкової школи, алгоритм організації формувального оцінювання, изілі навчання, критерії оцінювання, рефлексія, зворотній зв'язок.

“(C) Стребна О.В.

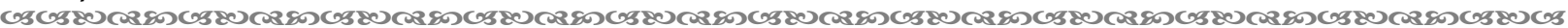

